\title{
Health Education for High School Students in Spain
}

\author{
David Pérez-Jorge ${ }^{1}$, María Dolores Jorge-Estévez ${ }^{2}$, Josué Gutiérrez-Barroso ${ }^{3}$, Milagros de la Rosa-Hormiga ${ }^{4}$ \& \\ María Sandra Marrero-Morales ${ }^{5}$ \\ ${ }^{1}$ Faculty of Education, Department of Didactics and Educational Research, Universidad de La Laguna (ULL), \\ Tenerife, Spain \\ ${ }^{2}$ Canary Health Care Service, Hospital Complex of Nuestra Señora de la Candelaria, Tenerife, Spain \\ ${ }^{3}$ Department of Sociology (Iriarte University School of Tourism), Universidad de La Laguna (ULL), Tenerife, \\ Spain \\ ${ }^{4}$ Faculty of Health Sciences, Nursing Department, Universidad de Las Palmas de Gran Canaria (ULPGC), Las \\ Palmas, Spain \\ ${ }^{5}$ Faculty of Health Sciences, Department of Modern Languages, Universidad de Las Palmas de Gran Canaria \\ (ULPGC), Las Palmas, Spain \\ Correspondence: David Pérez-Jorge, Faculty of Education, Department of Didactics and Educational Research, \\ Universidad de la Laguna (ULL), Tenerife, Canary Islands, Spain. E-mail: dpjorge@ull.edu.es
}

Received: March 29, 2016

doi:10.5539/ies.v9n10p185
Accepted: May 1, $2016 \quad$ Online Published: September 28, 2016

URL: http://dx.doi.org/10.5539/ies.v9n10p185

\begin{abstract}
Education and training in schools are essential elements in the development and socialization process of children from early childhood. The fact of considering health as a complete physical, mental and social wellbeing (World Health Organization (1848), WHO), and not only as the absence of illness, is closely related to the achievement of optimal levels of promotion and improvement in the quality of life and school performance in children. This research, carried out during the 2014-2015 academic year, attempts to analyze the ideas and attitudes of Compulsory Secondary Education (12 to 16 years old; compulsory) and High School (16 to 18 years; non-compulsory) students as regards health promotion in the school context. In order to perform this analysis, an ad hoc questionnaire was developed for 2337 students from the Province of Santa Cruz de Tenerife (Spain) and 15 follow-up interviews about the students' answers to emergency situations in the school context were also carried out. Both questionnaire and interviews revealed the existence of unhealthy habits related to the level of education, gender and health training of the students' parents. The results show that the "Questionnaire about attitudes and knowledge as regards health in the school context" (CACOSA) has been an adequate instrument to detect both important training needs and a lack of responsiveness to emergencies in secondary education schools as regards health education.
\end{abstract}

Keywords: behaviour, health, health education, health promotion

\section{Introduction}

The idea of illness in the collective subconscious of our society has negative connotations. The way in which situations of risk and prevention are faced is a very important aspect that, presently, has not been adequately studied. Both health and educational institutions have treated this topic differently, since there is no unified model which shows the best way to deal with health education. This research enhances the importance of the role of schools in order to teach topics related to health and disease in the educational process, as a part of people's vital process.

Health in the school context must not only be perceived from the fact of being healthy or unhealthy, but also from the acquisition of healthy attitudes and behaviours which help people face health and disease, letting them respond and solve those potential problems which can affect their health.

Generally speaking, the processes of representation and construction of concepts and attitudes are based on four essential elements which, in the case of health education, refer to: 1) information; what people know about health; 2) image; behaviours which people observe; 3) opinions; what they believe and 4) behaviours; what they do (Moscovici, 1989; Pérez-Jorge, 2010). This research aims at exploring ideas and attitudes of students as regards 
health and how to respond to emergency situations in schools. Falls, burns, epileptic seizures are common situations in educational centres. We understand that knowing how to respond to this type of situations is part of the set of behaviours which students must have. An adequate and rapid reaction reduces the risk and the possible consequences which result from school emergencies. Moreover, we consider that the knowledge of the students' lifestyle and the practice of unhealthy habits in the school context is essential to improve those habits related to health and healthy lifestyles.

\section{Review of Literature}

Health representation is closely related to psychological and socio-educational dimensions. It must be studied as a product and process of the same reality (Pérez-Jorge, De la Rosa-Hormiga, Pérez, Díaz-González, \& Marrero-Morales, 2015). In this sense, it is of crucial importance to analyze the processes of construction and representation of those concepts related to health and wellbeing. Moreover, it is important to take into account that the reinforcement of an idea about health in people is based on positive experiences which prompt further reflection on their state of mind. Health education appears to be, therefore, a necessary discipline to provide students with necessary means to prevent or modify risk behaviours (Macias, Gordillo, \& Camacho, 2012).

As Tallaferro (2012, p. 122) states, health concept representation is defined as "a mediation process between the idea of health and its perception, it is not only a mere intermediary but also a process that makes concept and perception become mutually influential."

When a person is asked about his/her idea of health and healthy life, the attitude, as a factor which influences them, is not mentioned. There appears instead a set of justifications and arguments which determine his/her way of acting or thinking in specific situations (Aguilar, De la Rosa-Hormiga, Herrera, Pulido, \& Díaz-González, 2014).

An attitude is a tendency of positive or negative response when facing certain situations or objects. These situations are made up of opinions and beliefs, feelings and patterns of behaviour and are responsible for the direction of our conducts (Pérez-Jorge \& Rodríguez, 2012). The opinions that a girl or a boy has about health and what is a healthy life are not intuitive. Those experiences in the relation with the environment, with those people around him/her and with those people they interact with, are essential in the construction of their ideas and opinions about health (Palomares et al., 2014). As García-Calvo, Sánchez-Oliva, Sánchez, Leo, and Amado (2012) state, these opinions arise after making individual assessments as the result of those interactions in the socialization process which is produced with the interaction with other people. In many cases, these interactions lead them to understand ideas and opinions of others. The information given to children, both in the family and in the school context, influences their opinions (Quarmby, 2013), promoting ideas and behaviours which will determine in the future their response, or, in other words, their attitude (Vázquez-Moralez \& Álvarez-Gordillo, 2016). In this sense, family and school play a very important role.

Children have to learn health education from enriching experiences through a framework for difference and diversity which lets them integrate and live positive experiences. In this sense, the influence of unhealthy social and cultural experiences have a lesser effect on what is considered as healthy habits, in other words, what is an adequate state of health (Pérez-Jorge, 2010; Fermán, Guzmán, Torres, Ahumada, \& Díaz, 2014). Therefore, to receive occasional information about health and healthy habits is not sufficient to ensure its assimilation since the previous social experience does not guarantee adequate opinions and beliefs. Thus, these authors consider that our social and cultural dimension of health can have conditioned opinions related to healthy habits, limiting or deteriorating attitudes and the practice of healthy habits.

School and family are social agents which play an important role in the creation of healthy habits and behaviours and in the promotion of a culture of health. There exist many researches which emphasize the importance of parents' participation in children's education, (Alfonso 2003; Botía, 2006; Cox, 2005; Desforges \& Abouchaar, 2003; Epstein, 2001; Fernández \& Fernández, 2014; Miranda, Romeu, Soler, \& Arrazola, 2014). They insist on the need to promote cooperation between parents and school teachers. According to these authors, this aspect is fundamental to consolidate all types of learning, including those related to healthy habits and behaviours. Studies about family-school cooperation (Sahota, Rudolf, Dixey, Hill, Barth, \& Cade, 2001; Salinas, González, Fretes \& Montenegro, 2014) reveal, in general, willingness to cooperate. However, they show little evidence as regards the continuity of the work which has to be performed with children at home. In this sense, they state that health education programmes must be planned and implemented in school centers by teachers, parents and the school community as a whole. Nevertheless, teachers think that there is no such involvement in the case of creating eating habits and promoting healthy attitudes and behaviours (Vio, 2015). These authors point out that this task is delegated to teachers. Therefore, family cooperation in these aspects is very low. 
On the other hand, we must consider that:

(...) parents' involvement is very important in children's health education. In this sense, the educational influence in students will be direct. They will be given adequate information to face, at home, those situations that can have a negative impact on health (Herrera, Fernández, González, \& Nápoles, 2014, p. 3).

The direct action as regards the correction of unhealthy habits is of crucial importance in order to consolidate healthy habits (Herrera, Fernández, González, \& Nápoles, 2014). In this sense, schools offer learning opportunities, using training strategies or the development of specific programmes. They try to promote in students positive attitudes towards healthy lifestyle habits which may not be as effective as those attitudes which can reinforce children's experiences in family contexts. Different studies performed by these authors make reference to the inadequate training and qualification of parents as regards health education and to the effect on the development of healthy habits in their children. The results obtained by these studies have proven the relation between the parents' lack of information about health and the development of unhealthy habits. Furthermore, they underlined the need to adapt teachers' training in the field of health education since many deficiencies were evident.

The attempts to analyze health education from both the educational sphere and the family background are becoming increasingly necessary. Therefore, we consider that there must be projections from school learning to family and social context. The effectiveness of collaborative work from all contexts which influence children's education is of crucial importance for its achievement (Henderson \& Mapp, 2002; Botía, 2006, Jeynes, 2007; Torrecilla, 2008). Recent studies such as those carried out by Hernández-Castilla, Murillo, and Martínez-Garrido (2016) and Suárez and Urrego (2015) show the lack of family involvement as one of the problems to improve training and efficacy in schools. In this sense,

(...) socialization processes are shared by school and family. However, changes in the different social areas have produced transformations in both. This fact has revealed variations as regards structure, function and conceptualization, giving rise to agreements and disagreements in such relation (Murillo \& Martínez-Garrido, 2016, p.18).

The diversity of family situations and their socioeconomic and educational reality has been a key conditioning factor in family-school relationships. Some studies related to the improvement of family-school relationships (Boult, 2006; Henderson, Mapp, Johnson, \& Davies, 2007; Hornby, 2000, Mercado \& Montaño, 2015, Seguí \& Pérez, 2015, González \& González, 2015, Murillo \& Martínez-Garrido, 2016) have demonstrated the need to make the effort towards the development of a collaborative work. Presently, no one questions the decisive role of the family in the improvement of children's processes of socialization and development due to the fact that there is a special influence of parents on the processes of acquisition of habits and behaviours which are relevant as regards health education (WHA).

As Macias, Gordillo and Camacho (2012) point out, in the 36th World Health Assembly, mention was made to the fact that health education had to include not only physical activity but those activities related to education and information which let people know different habits to get adequate levels of health. This Assembly emphasized the fact that any health-related situation could be an opportunity to learn about the different ways to maintain and care for health. Moreover, the Assembly placed a great emphasis on the potential value of other educational agents, such as the role of families. According to Macias, Gordillo and Camacho (2012, p. 42), "health education aims at designing intervention programmes focused on modifying unhealthy habits and beliefs". Moreover, as Farías and Alfaro (2004) state, health education also aims at promoting and protecting health. Nevertheless, from our point of view, this must not be the only way to address the promotion and development of a health culture since there are many researches which have focused their interest on schools as the key instrument to address this issue. Authors such as Palomares, Cimarro, Cepero, Torres, Estévez and Martínez (2014) think that schools have the important task of both transmitting values, attitudes and rules and promoting healthy sports habits and practices. In this task, the function of the teacher is of crucial importance and it must be exemplary (Contreras et al., 2010), since his/her way of acting and thinking as regards health issues will determine the acquisition and consolidation of his/her students' opinions (Maitles, 2010).

The changes in schools and the relevance of issues related to school health promotion have resulted in the development of programmes, especially in the area of physical education, addressed to work the development of health values. Experiences such as those developed by Sáenz-López, Sicilia, and Manzano, (2010) have elicited positive effects which have produced a change in the way of addressing values education, especially those related to health and the development of healthy habits and behaviours. The proposal designed by these 
researchers through the project "Educating and training parents..." (Palomares, Cimarro, Cepero, Torres, Estévez, \& Martínez, 2014, p. 137) let parents cooperate in social development skills to promote the interrelation with their children through play and sport as practices of a healthy lifestyle. This programme let those participating parents value their role in the development of healthy practices and accept their responsibility which, as parents, they must assume in their children's education. This experience reflects what at present is considered as an approach of families to schools. However, as an experience, we cannot consider it as a widespread reality. We know that the family atmosphere and the family-school relationship depend on many factors. The idea of education as something only related to school as the institution which has to educate children is, at present, far from reality (Epstein, Galindo, \& Sheldon, 2011; Comellas, 2009; Fernández-Enguita, 2006).

Over the last years, the relation between families and schools and their ways of participation has been extensively studied. Researchers such as Ibáñez (2014), Vega (2012), Muñoz and Gairín (2011), Garreta (2007, 2008, 2012, 2014), Miranda, Romeu, Soler, and Arrazola (2014), Martínez, Reche, Cerezo, Maíquez, and García (2014) have stated that:

a) The situation of family cooperation in schools has not changed, in spite of the fact that there are advances and legislative proposals to promote it.

b) Family participation and involvement in children's learning processes "depend on subjective variables, on the individuals' motivations and interests and on the facilities and difficulties which they can show to let school administrators and teachers participate and carry out their work" (Miranda, Romeu, Soler, \& Arrazola, 2014, p. 85).

c) The involvement of families in schools is occasional and isolated.

d) There is no real cooperation culture, the level of family involvement has an individual character and is related to the student's performance in the different topics or subjects.

If we take into account that family and school are the basic environments of influence and education in children in all contexts, and more specifically in the educational context, we have to consider that in the past few years both environments have experienced important changes which have been able to affect the development of habits and behaviours related to health. The first and most important learnings about health take place at home and during the first years of the children's life (Rosales, 2006, 2011; López, 2014). This situation has changed significantly in the last few years. In this sense,

(...) home influence is not, at present, as great as in other times. This is due to the small size of the family, usually made up of a father, a mother and a son/daughter. These are nuclear families in which grandparents are not usually present or families which lack, in many cases, brothers or sisters. If both parents work, the time they are at home and which, therefore, can devote to their children is short. This situation means that children have to attend school from a very early age and, most of the times, parents leave them with people who do not belong to the family (López, 2014, p. 291).

As regards the school context, there exists a series of circumstances that can affect those learnings related to the field of health. Health education has a particular relevance in pre-school and primary-school years since these years are essential for the acquisition of healthy habits and behaviours and "constitute the period of schooling which all citizens are going to perform and let all population have a common basic education in the field of health" (López, 2014, p. 291). However, concern remains about its treatment and approach from the educational point of view since it lacks an own space or specific curricular area to carry out such approach. Health education is approached implicitly by means of a set of conventional curricular areas (Ministry of Education and Science (MEC), 1993; Rosales, 1999, 2006). There are many evidences which show the need for a review of the treatment and approach to health education (Pérez-Jorge, De la Rosa-Hormiga, Pérez, Díaz-González, \& Marrero-Morales, 2015). In this sense, it seems to be necessary to improve certain aspects (Rosales, 2011):

a) The level of cooperation among parents and among parents and teachers with the aim of providing continuity and coordinating learning in both contexts.

b) Coordination among teachers and specialists. It makes education become a collaborative work. As López states, "the relationship among parents and specialists in psychopedagogy, therapeutic pedagogy, medicine and sociology seems to be particularly recommendable in the teaching of topics such as drug consumption, sexual education and AIDS" (López, 2014, p. 294).

c) Coordination among schools, city councils and public and local administrations.

d) Cooperation among the media, schools and families since children "spend a lot of time in front of screens. 
It is necessary to produce educational TV programmes in time slots where mainly children are watching TV, reducing, therefore, violent advertising contents" (López, 2014, p. 294).

The present society suffers from important problems related to health. According to WHO (2014), in the last years problems related to cardiovascular diseases, cancer, drug dependencies, sexually transmitted diseases, dementia, chronic obstructive pulmonary disease and diabetes have increased. Presently, health authorities are particularly concerned with this situation and they require a series of measurements to prevent them. As Nieda points out (1992, p. 9), "health education not only contributes to have a better health state and to prevent illnesses but also to promote the recovery from illnesses". Consequently, this author considers that the more people know about the causes of disease and the way to face them, the greater the possibilities to reestablish their state of health. We also consider that it is of crucial importance to know how to respond to emergency situations in order to decrease the risks produced by the students' inappropriate actions.

The present study is based on a previous research carried out by de la Rosa (2014). This research was performed in different educational centres in Canary Islands (Spain), which belong to the Network of Health Promoting Schools (NHPS). This network is part of a project of the Canarian Government which appears to be a health promotion strategy in the educational context and a mechanism which articulates multi-sectoral efforts and resources oriented to the improvement of health and welfare conditions from a comprehensive approach. It was created with the aim of contributing to the establishment of the reinforcement of the competencies learning approach, providing, therefore, real contexts and situations of interest for the promotion of values, habits and healthy lifestyles. The results of the study by De la Rosa (2014) gave rise to a lot of questions which have been considered in this study. The persistence of unhealthy practices and habits and students' improper reactions to emergencies opened the door to this study.

Therefore, the specific objectives stated in this study were the following ones:

a) To examine the students' level of knowledge about school health.

b) To know the students' attitude and predisposition to learn to solve situations related to health problems.

c) To value the adequacy of students' responses to common accident situations (falls, burns, epileptic seizures).

d) To know the differences as regards health knowledge, taking into account their parents' educational level, gender and health education.

\section{Method}

The sample selected was taken, with prior written consent, signed by the families, from the population of students in the first and second cycle of Compulsory Secondary Education (students from 12 to 18 years old) in the province of Santa Cruz de Tenerife (Spain). The sample was made up of 2337 students. $45 \%$ (1103) were students in secondary education centres (ESO; 12-16 years old) and 55\% (1234) were students in secondary schools (IES; 16-18 years old).

$66.3 \%$ of students were teenagers 14 to 16 years old (Compulsory Secondary Education students) and $33.7 \%$ of students were over 16 years old (High School students). 52.5\% were male students and $47.5 \%$ were female students. As regards the school centers, we could state that $54.2 \%$ studied in private education centers whereas 45.8\% studied in public teaching centers. $27.9 \%$ were students whose parents (one or both) were health professionals (doctors, nurses, nursing assistants, pharmacists and psychologists).

Taking into account that the secondary school students' population in the Province of Santa Cruz de Tenerife was 86899 , the sample obtained showed a confidence level of $95 \%$ and a sampling error of \pm 2 , being the students' average age of 15.2 years old $(\mathrm{Sd}=1.31)$.

\section{Instrument}

The instrument which is proposed to evaluate students' attitudes and knowledge in the field of health education was a questionnaire prepared for this study taking into account the most common situations about school health and emergencies (Pérez-Jorge, De la Rosa-Hormiga, Pérez, Díaz-González, \& Marrero-Morales, 2015).

The questionnaire used was an ad hoc test adapted to the objective of the study. The Questionnaire about attitudes and knowledge as regards health in the school context (CACOSA) was performed using Lickert Scale and taking as a basis the Healthy Child Programme conducted by the Canary Islands Health Service 2007. This questionnaire was taken from a research by De la Rosa (2014), who applied to a similar sample a first version adapted to the students' characteristics. 
In order to review and adapt this instrument, the procedure carried out by Pérez-Jorge, Alegre, Rodíguez-Jimenez, Márquez-Dominguez, and De la Rosa (2016) was adopted. Thus, we performed a second version of the instrument, which was tested for content validity according to McMillan and Schumacher (2005):

a) Pilot test: a test conducted among 20 students which have the same characteristics of those students in the final sample, to define content and writing aspects of the different items, and comprehension and adequacy of answer options.

b) Content analysis performed by university professors: the analysis was carried out by four university professors who belonged to the field of health and education, in order to evaluate if the items included were relevant and appropriate and if they covered the dimensions studied.

Taking into account the results obtained in the validity tests, the final version of the questionnaire was carried out. It was finally made up of eight variables related to identification, knowledge and experience, two dichotomous variables about health beliefs and thirty seven variables with a format of assessment scale in which each item was valued punctuating from 1 (the lowest level of agreement) to 6 (the highest level of agreement), according to the students' opinions: a) Students' attitude towards health education, b) Prevention of and attention to risk situations and the most frequent illnesses in school age, c) Accidents and emergencies in the school context, d) Obesity prevention and e) Prevention of addictive behaviours. Each item was valued punctuating from 1 (the lowest level of agreement) to 6 (the highest level of agreement).

Furthermore, a semi-structured interview was carried out to 15 students who wanted to participate voluntarily in this study, with the aim of analyzing the knowledge about procedures and protocols to respond to school emergencies (Heimlich maneuver, external hemorrhages, epilepsy and burns).

Taking into account the objectives proposed in this research, the following analysis procedures were carried out: 1) Cronbach's Alpha was used to evaluate the internal consistency of the test, both globally and taking into account each content dimension; 2) to analyze the underlying structure, a Principal Component Analysis was performed (PCA); 3) to know the answers given by the students a descriptive and exploratory analysis of the factors obtained from the PCA was carried out; 4) Moreover, relations among sample characteristics and the dimensions of the test were analyzed.

\section{Results}

\subsection{Analysis of Internal Consistency}

Taking into account the levels of reliability proposed by George and Mallery (2003), we can state that, at a global level, all the items reached a high coefficient $(0,0.867)$. This fact let us consider the adequate reliability of the instrument.

Table 1 shows the results obtained after the reliability analysis (Cronbach's Alpha) of the thirty seven items divided into five subscales.

Table 1. Analysis of the reliability of the questionnaire; subscales, number of items and value of Cronbach's Alpha internal consistency coefficient

\begin{tabular}{lcc}
\hline Subscales & $\begin{array}{c}\mathrm{N}^{\mathbf{0}} \\
\text { items }\end{array}$ & $\begin{array}{c}\alpha \\
\text { Cronbach }\end{array}$ \\
\hline 1. Student's attitude towards health education & 13 & 0,901 \\
2. Prevention of and attention to risk situations and the most frequent illnesses in & 8 & 0,800 \\
school age & & \\
3. Accidents and emergencies in the school context & 4 & 0,781 \\
4. Prevention of obesity & 8 & 0,789 \\
5. Prevention of addictive behaviours & 4 & 0,809 \\
Total & 37 & 0,877 \\
\hline
\end{tabular}

Source: Based on the results obtained from the "Questionnaire about attitudes and knowledge as regards health in the school context" (CACOSA). 


\subsection{Analysis of Test Structure}

Taking into account the results obtained in each of the items, an analysis of the main components was performed through the VARIMAX rotation procedure. The index KMO of sampling adequateness obtained an acceptable value and enabled us to proceed with factorization (Bartlett test of sphericity; $\chi 2=326.2,1325 \mathrm{gl}, \mathrm{p}<0.000$ ). We decided to opt for 5 components which explained a $60.7 \%$ of the variance. The variance percentage which each factor explained and their own values are shown in Table 2.

Table 2. Factors obtained showing the number of item and factorial weight, with percentage of variance of each factor

\begin{tabular}{|c|c|}
\hline & $\begin{array}{l}\text { Factorial } \\
\text { weight }\end{array}$ \\
\hline \multicolumn{2}{|l|}{ Factor I $(\%$ rotation variance $=16,831)$} \\
\hline I would like to be taught about health and healthy lifestyle habits (25) & ,812 \\
\hline I think that all the information about health is useful (26) & ,713 \\
\hline I am very satisfied when I solve an emergency (27) & ,607 \\
\hline It is very important to have knowledge about first aid measures (28) &, 519 \\
\hline I have received health education from my parents and relatives (29) &, 571 \\
\hline I have no concern about health issues (30) &, 530 \\
\hline I enjoy learning new things which help me feel healthy (31) & ,482 \\
\hline I usually ask my teachers questions about health (32) & ,461 \\
\hline I have learned all what I know about health through the use of the Internet (33) & ,436 \\
\hline To know about health is also useful for my daily life (34) & ,430 \\
\hline When I have a doubt about health, I let it pass and I try to get information about it (35) & ,429 \\
\hline I think that each educational center should have a health professional (36) & ,424 \\
\hline \multicolumn{2}{|l|}{ Factor II $(\%$ rotation variance $=15,820)$} \\
\hline Vaccines are administered to cure some diseases (4) &, 813 \\
\hline Insulin is a medication you can keep anywhere (7) & ,796 \\
\hline Adults are the only ones who suffer from diabetes (8) & ,762 \\
\hline A temperature of 37 degrees Celsius is considered as a degree of fever (12) & ,713 \\
\hline I usually wash my hands everyday (16) & ,621 \\
\hline Condoms prevent pregnancies but they do not prevent sexually transmitted diseases (17) &, 594 \\
\hline Teeth must be brushed once a day at night (23) & ,493 \\
\hline Epileptic people can have seizures (24) & ,441 \\
\hline \multicolumn{2}{|l|}{ Factor III $(\%$ rotation variance $=11,056)$} \\
\hline If there is bleeding, a tourniquet must be applied (13) & ,683 \\
\hline The first thing to do when a student faints is to call the teacher (19) &, 579 \\
\hline The first thing to do when there is a burn is to apply hydrogen peroxide (20) &, 527 \\
\hline If a student is choking, we should give him back blows (14) &, 512 \\
\hline \multicolumn{2}{|l|}{ Factor IV $(\%$ rotation variance $=9,401)$} \\
\hline Pasta and bread are protein-rich foods (1) & ,739 \\
\hline Bulimia is a blood disorder (2) & ,667 \\
\hline Celiac people cannot eat vegetables and fruits (3) & ,642 \\
\hline A healthy diet is made up of carbohydrates, proteins and fat (5) &, 594 \\
\hline
\end{tabular}


I practice sports at least three times a week (18) , 547

A diabetic person can eat anything (21)

I consume soft drinks and tetra brik juices everyday (22)

Factor IV $(\%$ rotation variance $=7,614)$

Cocaine is a drug (9) , 779

I am always thinking about the Internet when I am doing other things (10)

Marijuana creates addiction (11)

Alcohol is a drug (15)

Source: Based on the results obtained from the "Questionnaire about attitudes and knowledge as regards health in the school context" (CACOSA).

After the analysis of the items collected in this questionnaire (CACOSA), the following five major factors were obtained:

1) Students' attitude towards health education. This factor collects items related to students' opinions and attitudes towards health education.

2) Prevention of and attention to risk situations and the most frequent diseases in school age. This component refers to those items related to aspects which have to do with common diseases in schools and the way to avoid risks in the school context.

3) Accidents and emergencies in the school context. This factor comprises those items related to the way of reacting in school emergencies.

4) Obesity prevention. This component is made up of those items related to students' perception and knowledge about eating habits.

5) Prevention of addictive behaviours. This factor comprises items related to students' perception and knowledge about certain addictive behaviours.

\subsection{Knowledge and Attitude as Regards Health Education}

$85 \%$ of students who participated in this study perceived themselves as healthy people compared with $15 \%$ of students who recognized they did not perceive themselves as healthy individuals.

As regards those people who have given them information about health issues and those who have instilled healthy habits in students, we can state that in general there are low percentages in all the fields which have been analyzed, being the most remarkable the low percentage perceived by students as regards the school as promoter of healthy habits $(12 \%)$. Other aspect to take into account was the fact that the students received information about health from their doctors (68\%) and friends (39\%). These results can be shown in Figure 1.

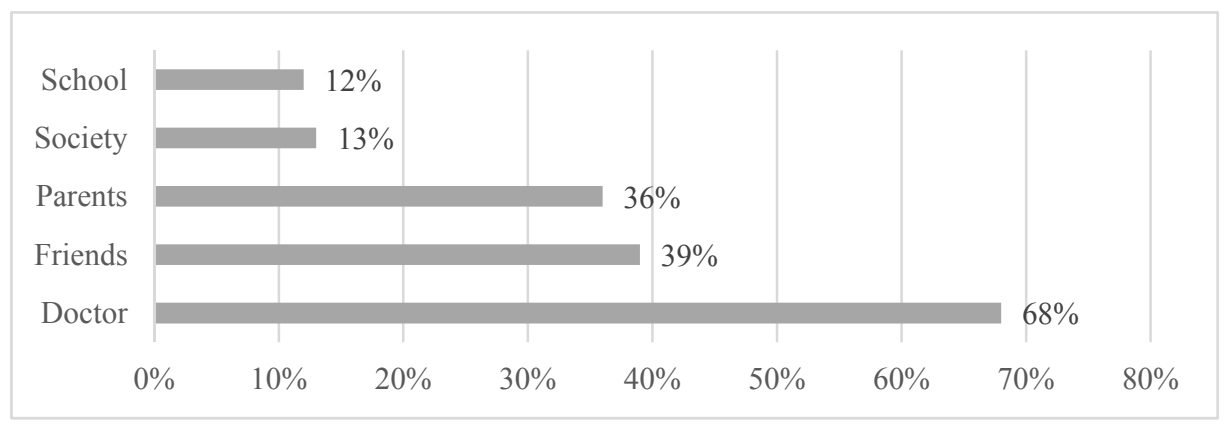

Figure 1. Percentage of students' answers taking into account those who inform them about health

Source: Based on the results obtained from the "Questionnaire about attitudes and knowledge as regards health in the school context" (CACOSA). 
As regards the sufficiency and adequacy of the information received by the students, we can state that, in general, they considered that the information received from parents, school, friends and society was insufficient. It is important to take into account that the students perceived that they received little information about health from school in compulsory secondary school education $(15 \%)$. They considered that they received information especially from their doctors and pediatricians (82\%). These results can be shown in Figure 2.

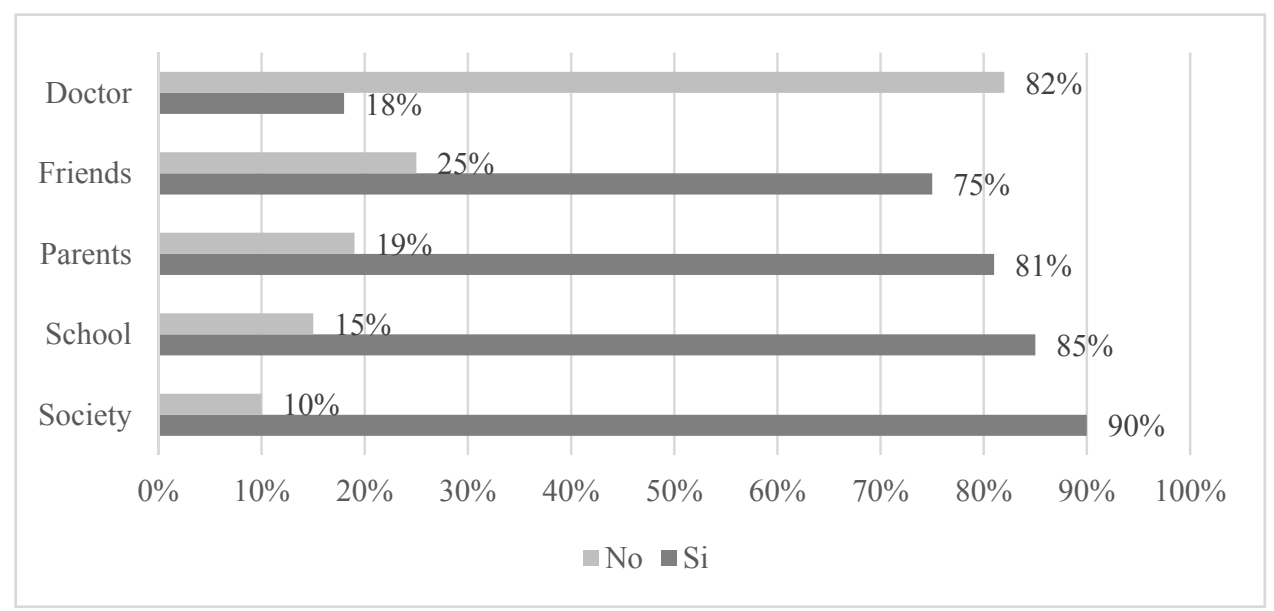

Figure 2. Percentages of answers from different informants

Source: Based on the results obtained from the "Questionnaire about attitudes and knowledge as regards health in the school context" (CACOSA).

Different opinions given by the students were analyzed (parametric Student $t$ test and a one-way Anova), with the aim of exploring the differences as regards gender, educational level, type of educational center and parents' health education. In order to analyze these differences, five new variables were created from the mean values of the items of each factor and they were included as contrast variables, obtaining for each one the following mean values: 1) Prevention of addictive behaviours (Med=4.37), 2) Food and nutrition (Med=4.44), 3) Prevention of and attention to risk situations and the most frequent illnesses in school age(Med=4.37), 4) Accidents and emergencies in the school context (Med=4.33) and 5) Students' predisposition and attitude towards health education. (Med=4.31). These results can be shown in Figure 3.

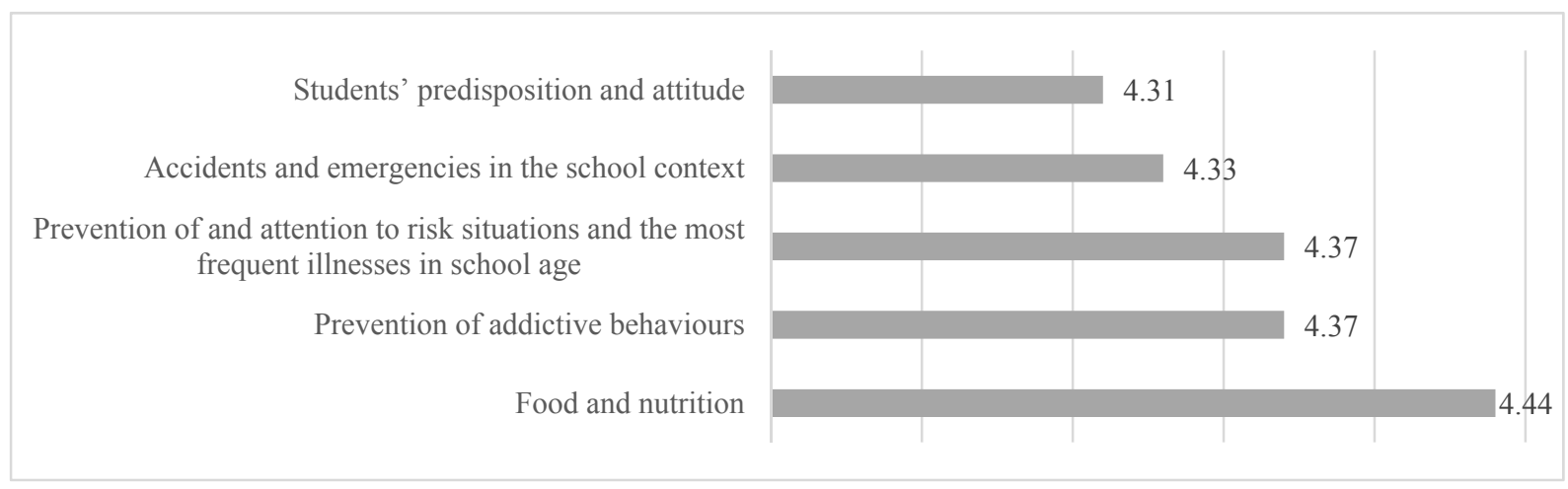

Figure 3. Mean values of CACOSA dimensions

Source: Based on the results obtained from the "Questionnaire about attitudes and knowledge as regards health in the school context" (CACOSA).

The results show differences as regards:

Educational level; the differences obtained only refer to dimensions 2 and 3. It was stated that high school 
students $\left(\bar{x}_{2}=4.52\right)$ had a better perception and knowledge about eating habits than compulsory secondary education students $\left(\bar{x}_{1}=4.23\right) .(\mathrm{F}(1.2)=, 526 ; \mathrm{p}=.001)$. As regards prevention of and attention to risk situations and most common illnesses in school children (2), an opposite tendency was observed in the mean values obtained. Compulsory secondary education students $\left(\bar{x}_{1}=4.59\right)$ had more knowledge about the aspects related to common school illnesses and how to avoid risks related to health in the school context than high school students $\left(\bar{x}_{2}=4.37\right)$. $(F(1,2)=1.966 ; \mathrm{p}=.006)$.

Gender; differences as regards dimensions 1 and 5 were found in the study. Significant differences were also observed between male and female students related to prevention of addictive behaviours (1) and students' predisposition and attitude (5). Male students $\left(\bar{x}_{1}=4.49\right)$ showed a better perception and knowledge about certain addictive behaviours than female students $\left(\bar{x}_{2}=4.24\right) .(F(1,2)=, 389 ; \mathrm{p}=.009)$ Furthermore, it was observed that female students $\left(\bar{x}_{2}=4.46\right)$ obtained higher mean values $\left(\bar{x}_{1}=4.18\right)$. $(F(1.2)=6.921 ; p=.001)$ than those observed in male students as regards their opinion and attitude towards health.

Health education and training of the students' parents; differences as regards factors 1, 4 and 5 were found. Students whose parents are health care professionals $\left(\bar{x}_{1}=4.82\right)$ show more predisposition to prevent addictive behaviours than those students whose parents are not health care professionals $\left(x_{2}=4.31\right) .(F(1,2)=14.031$; $p=.002)$. On the other hand, students whose parents are health care professionals $\left(\bar{x}_{1}=4.63\right)$ show a better knowledge about how to deal with school emergencies tan those students whose parents are not health care professionals $\left(\bar{x}_{2}=4.21\right) .(F(1.2)=15.032 ; p=.001)$. Moreover, there were also differences as regards students' predisposition and attitude towards health education: students whose parents are health care professionals $\left(\bar{x}_{1}=\right.$ 5.02) obtained_higher mean values than those obtained by students whose parents are not health care professionals $\left(\bar{x}_{2}=4.17\right) .(F(1,2)=13.025 ; p=.000)$. Furthermore, it was observed that, in general terms, they devote more hours to studying, connect less to the internet and practice more sports than the other students.

As regards the possible dependencies and unhealthy practices in school age children, it was stated that the students study between 1 and 10 hours a week (48.7\%), spend many hours connected to the Internet $(67.5 \%)$ and practice sports between 1 and 10 hours a week (68.40\%). See Figure 4.

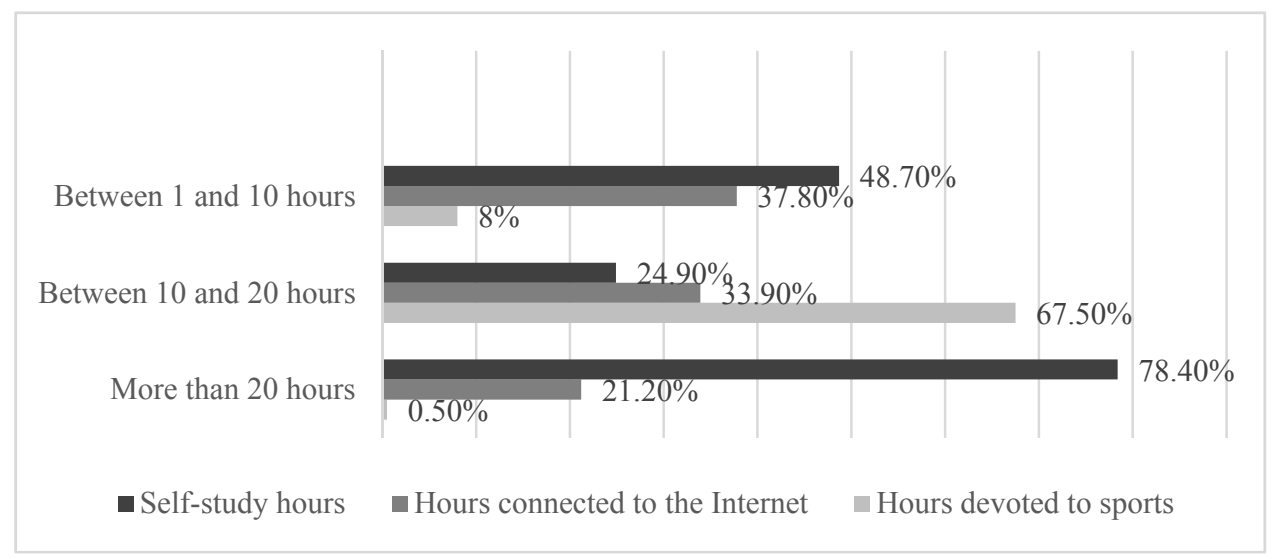

Figure 4. Percentage of daily health-related habits

Source: Based on the results obtained from the "Questionnaire about attitudes and knowledge as regards health in the school context" (CACOSA).

In relation to the students' experience as regards their classmates' illnesses or health problems, it can be stated that the students, in general, have experiences with classmates who suffer from asthma or consume drugs. As regards the other aspects, the students expressed that they had little or no experience. See Figure 5. 


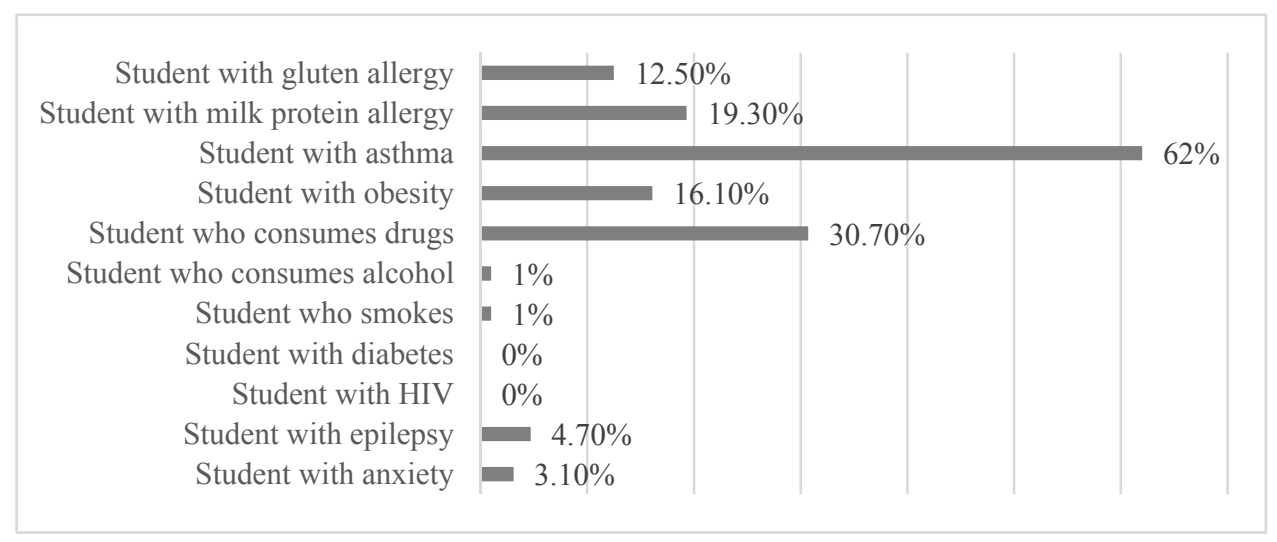

Figure 5. Percentages of students with school experience as regards their classmates' illnesses

Source: Based on the results obtained from the "Questionnaire about attitudes and knowledge as regards health in the school context" (CACOSA).

\subsection{Results Obtained in the Students' Interviews}

In order to facilitate the interpretation of the answers given by the students, all the answers have been categorized according to a series of school emergency situations (choking, haemorrhages, epileptic seizures and burns). Each student was identified according to the following code "Pn", where "P" refers to "participant" and "n" to the number of participant who answers each question.

1) Choking: As regards this emergency situation, $72 \%$ of students admitted they did not know how to face this situation properly. The answers given by the students are shown in Figure 6. Furthermore, $72.2 \%$ of students would put into practice a supra-diaphragmatic abdominal compression which is considered as an inadequate maneuver in case of choking. The answers given by the students (see figure 6) revealed a lack of knowledge about the actions which should be performed to assist someone who is choking. Among the answers we mention the following ones: (P3): "if a classmate is choking, I ask him to look up and I give him back blows with an open hand", (P9): "I sit him in a chair and I give abdominal thrusts", (P14) "I surround his back with my arms, lifting and moving him", (P6): "I would not know what to do, probably I would leave him and run to try to find some help".

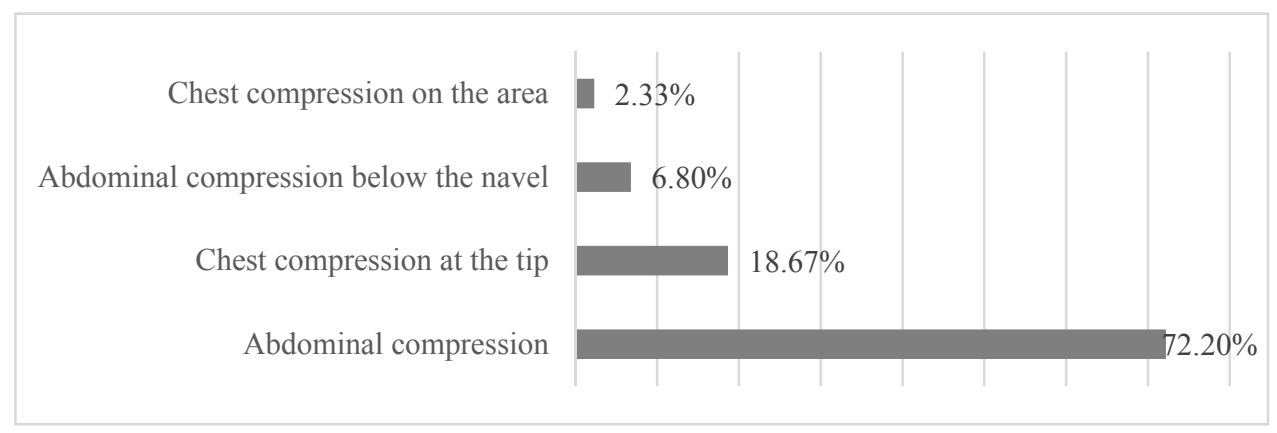

Figure 6. Percentage of students' type of reaction to choking

Source: Based on the results obtained from the "Questionnaire about attitudes and knowledge as regards health in the school context" (CACOSA).

2) Haemorrhages: as regards this emergency situation (Figure 7), the students answered that they applied direct pressure to the wound for a few minutes $(68.40 \%)$. This answer seems to be more a natural or intuitive answer than a correct one. The high percentage of answers given by students show that most of them would not know how to respond to an emergency situation. Furthermore, $6.46 \%$ of students answered inappropriately when they answered that they would apply a tourniquet or direct pressure to the wound (see Figure 6). Among the answers 
we can mention the following ones: (P7): "blood scares me a lot, I would cover the wound with a cloth or a tissue and press hard; (P13): "I have seen in movies that a tourniquet is applied with a stick or a cloth"; (P8): "I have only seen haemorrhages from the nose. I do what my parents have taught me at home. I put a cotton swab in his nose and pour water on his head. It always works and I do it to my friends when it happens to them".

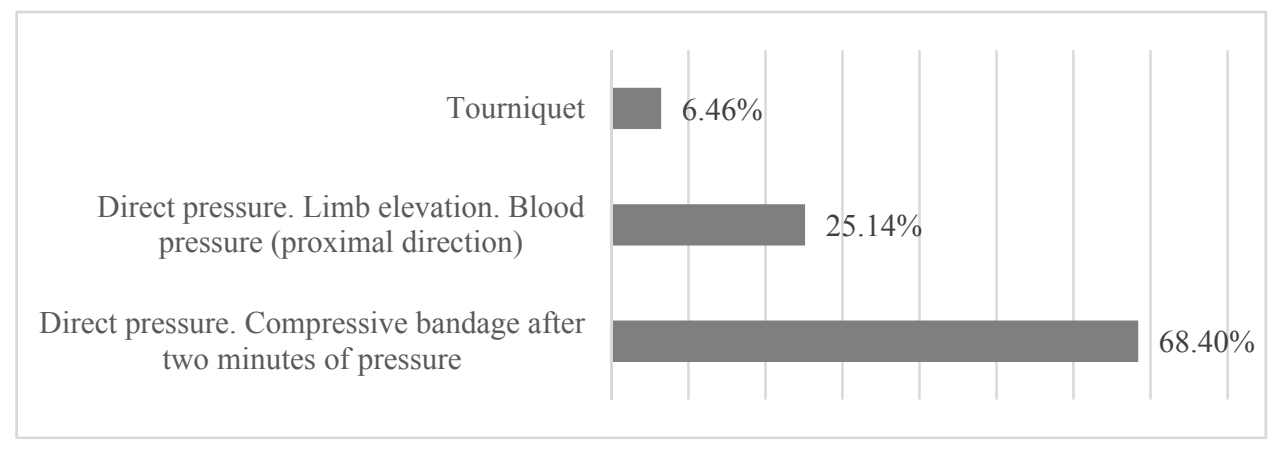

Figure 7. Percentage of students' type of reaction to haemorrhages

Source: Based on the results obtained from the "Questionnaire about attitudes and knowledge as regards health in the school context" (CACOSA).

3) Burns: the students answered inadequately as regards those questions related to their reaction to burns. $69.4 \%$ of students think the affected area should not get wet (Figure 8). This answer revealed a considerable lack of knowledge about the adequate way to react to this accident. Among the answers we can mention the following ones: (P1): "I will always try to rinse the wound with cool water to relieve burning"; (P10): "I would remove clothing"; (P15): "I would give him a lotion or put toothpaste on the wound as my parents give me at home to avoid pain. I would cover his burn to avoid pain".

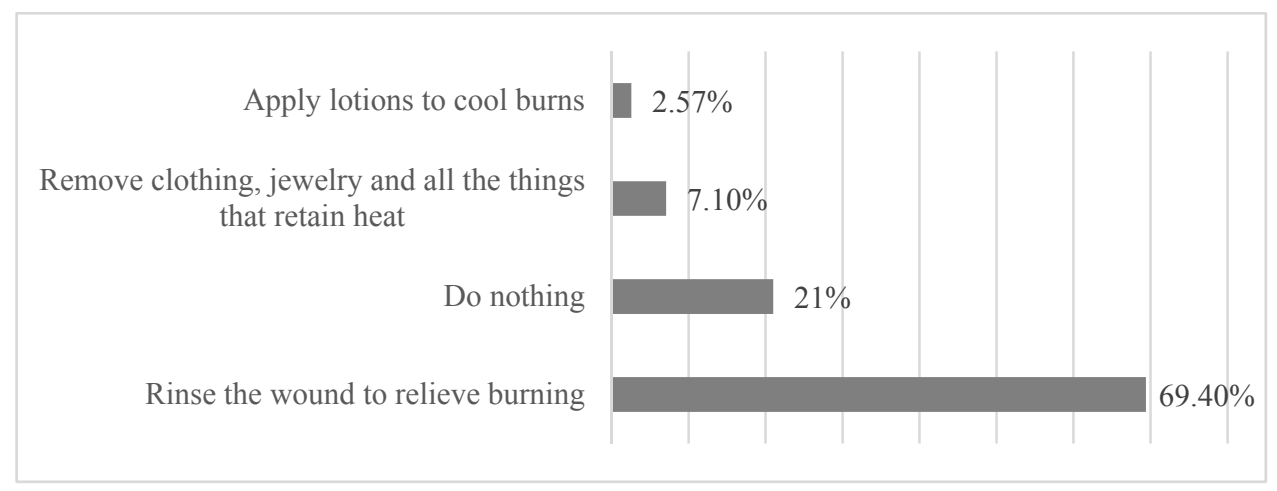

Figure 8. Percentage of students' type of reaction to burns

Source: Based on the results obtained from the "Questionnaire about attitudes and knowledge as regards health in the school context" (CACOSA).

\section{Discussion and Conclusions}

After studying CADESO metric properties, we can state that this instrument is both reliable and adequate. Moreover, with this instrument we could apply a procedure to reduce data which let us perform the analyses of this study. All the factors obtained have proven to be coherent with the theoretical dimensions proposed (Pérez-Jorge, De la Rosa-Hormiga, Pérez, Díaz-González, \& Marrero-Morales, 2015). Therefore, these factors were used to perform the analysis of the results.

This research about knowledge regarding health, healthy habits and response to emergencies in compulsory secondary education students and high school students, revealed that presently there is an important lack of education and training which affects both students and educational institutions. In this sense, health education 
does not fulfill one of its main objectives. This fact has prevented students from acquiring the necessary education and experience to avoid or modify risk behaviours (Macias, Gordillo, \& Camacho, 2012).

The results obtained are relevant as regards the low level of training and the response capacity which compulsory secondary education students and high school students from ordinary educational centers have in order to develop healthy habits and the assistance to classmates who could, for some reason, suffer from any accident in the school center. Learning based on experience is limited and the education or training they receive about health is occasional, insufficient and delayed (Pérez-Jorge, 2010; Fermán, Guzmán, Torres, Ahumada, \& Díaz, 2014). Thus, the results show the lack of reinforcement of these learnings.

As regards attention to and prevention of risk situations and most common illnesses in school age children, compulsory secondary education students show more knowledge about those aspects related to common illnesses in the school context and the way to avoid health risks than high school students. This fact could be produced by the inherited education or training from primary schooling (López, 2014), which put a greater emphasis on this education. The existence of unhealthy habits and behaviours was particularly significant in students whose parents did not have medical training. Parents' training and qualification were considered as a key element to adopt and maintain healthy habits and behaviours. This fact revealed the importance of the close contact with information and experiences related to health in order to maintain it. Students whose parents are health care professionals show a better knowledge about how to deal with school emergencies, devote more hours to studying, connect less to the internet and practice more sports than the other students. The direct experience of those students with health professional parents was essential to consolidate healthy habits (Herrera, Fernández, González, \& Nápoles, 2014).

On the other hand, male students have a better perception and knowledge about certain addictive behaviours than female students. However, female students have a better opinion and attitude towards health education than that shown by male students.

In general, we can state that there exists a lack of knowledge among students as regards the way to react to emergency and risk situations. The results obtained have proven that the ways of acting were not adequate and they, moreover, implied a risk as regards the consequences of such actions. These results obtained in the stage of compulsory secondary education and high school have proven to be worrying and have revealed the need to improve the learning processes as regards health education from the school, family and community settings. Therefore, it is necessary to improve the cooperation process of family, school and health professionals to obtain successful formative interventions from a transdisciplinary and transtemporal approach which lets educational institutions be involved, expanding this education to the individual's life (Sahota, Rudolf, Dixey, Hill, Barth, \& Cade, 2001; Salinas, Lera, González, \& Huenchupán, 2012).

The lack of an area of curriculum development and the lack of learning projection in close and family settings are both realities which have been reflected in the students' answers. Therefore, we consider of crucial importance to review the treatment, approach and scope of health education. The results of this research show an important lack of education and development of healthy habits in compulsory secondary education and high school. Consequently, we consider that it is necessary to educate and inform students and families about unhealthy practices, as a mechanism to prevent the development of unhealthy habits and behaviour (López, 2014).

As a summary, we can state that:

a) The instrument used to assess the students' attitudes and knowledge about school health has been adequate and reliable.

b) There are important educational deficiencies as regards training and awareness on health issues. In this sense, health education has not promoted the necessary training and experience to prevent or modify risk behaviours.

c) High School students showed a limited training and capacity to assist their classmates in emergency situations in the school context and have not adequately developed healthy habits and behaviours.

d) The contact with information and experiences related to health were essential in order to develop healthy habits and behaviours.

e) Male students have a better knowledge of addictive behaviours than female students, who showed a better attitude towards values acquisition.

We suggest that studies like this be carried out in other Spanish autonomous communities or in other countries in 
order to compare results and take adequate measures to improve the educational approaches and the students' experiences related to the development of healthy habits and the adequacy of their responses to school emergencies.

\section{References}

Aguilar S., De la Rosa-Hormiga, M., Herrera, J, M., Pulido, F., \& Díaz-González, C. (2014). Variables of Suicidal Behavior in Tenerife Years 2011-2012: Proposals for the Prevention. Forensic Medicine and Anatomy Research, 37-41. http://dx.doi.org/10.4236/fmar.2014.22007

Alfonso, C. (2003). La participación de los padres y madres en la escuela. Barcelona, España: Graó.

Botía, A. B. (2006). Familia y escuela: Dos mundos llamados a trabajar en común. Revista de educación, 339, 119-146.

Bouché, H. (2004). Salud y educación en las culturas. Educación para la salud: Reto de nuestro tiempo, 50205, 22.

Boult, B. (2006). 176 ways to involve parents: Practical strategies for partnering with families. Oaks, California: Corwin Press.

Comellas, M. J. (2009). Familia y Escuela. Compartir la educación. Barcelona, España: Graó.

Consejería de Educación del Gobierno de Canarias. (2016). Red de Escuelas Promotoras de Salud (REPS). Canarias; España. Retrieved from http://www.gobiernodecanarias.org/educacion/web/programas-redeseducativas/redes-educativas/rceps/que-es.html

Contreras, O., Gil, P., Sebastiani, E., Pascual, C., Huguet, D., Hernández, J. L., \& Capllonch, M. (2010). Didáctica de la educación fisica, 2. Ministerio de Educación.

Cox, D. (2005). Evidence-based interventions using home-school collaboration. School Psychology Quarterly, 20(4), 473-97. http://dx.doi.org/10.1521/scpq.2005.20.4.473

De la Rosa, M. (2014). Conocimientos y actitudes de profesores y alumnos sobre educación para la salud en el ámbito escolar. La Laguna, España: Ediciones de la Universidad de La Laguna.

Desforges, C., \& Abouchaar, A. (2003). The impact of parental involvement, parental support and family education on pupil achievement and adjustment: A review of literature. London: DfES Publications.

Epstein, J. (2001). School, family and community partnerships. Boulder, CO: West view Press.

Epstein, J., Galindo, C., \& Sheldon, S. (2011). Levels of leadership: Effects of district and school leaders on the quality of school programs of family and community involvement. Educational Administration Quarterly, 47(3), 462-495. http://dx.doi.org/10.1177/0013161X10396929

Fermán, I., Guzmán, F., Torres, A., Ahumada, C., \& Díaz, F. (2014). Estrategia para modificar conocimientos y actitudes en niños escolares: un programa de educación para la salud. Psicología y Salud, 14(1), 135-142.

Fernández, M., \& Fernández, M. (2014). Beneficios de la participación de la familia en la evaluación del aprendizaje de los estudiantes. Sustentabilidad al Día, 4.

Fernández-Enguita, M. (2006). Tiempo, escuela y sociedad. Kikiriki, 69, 22-25.

Figueroa, I., Farías, M., \& Alfaro, N. (2004). Educación para la Salud: La importancia del concepto. Revista de Educación y Desarrollo, 1(6), 43-48.

García-Calvo, T., Sánchez-Oliva, D., Sánchez, P., Leo, F., \& Amado, D. (2012). Escuela del deporte. Valoración de una campaña para la promoción de los valores. Motricidad: revista de ciencias de la actividad física y del deporte, 28, 67-81.

Garreta, J. (2008). La participación de las familias en la escuela. Las asociaciones de madres y padres de alumnos. Madrid, España: CIDE/CEAPA.

Garreta, J. (2012). Famílies i escoles. La participació de les famílies als centers educatius. Lleida, España: Ayuntamiento de Lleida.

Garreta, J. (2014). La participación de las familias en la escuela: una cuestión pendiente. Documentación Social. Revista de Estudios Sociales y Sociología Aplicada, 171, 101-124. http://dx.doi.org/10.15257/ehquidad.2014.0009

Garreta, J. (Ed.) (2007). Las relación familia-escuela. Lleida, España: Ediciones de la Universidad de Lleida. 
George, D., \& Mallery, P. (2003). Frequencies. SPSS for Windows step by step: A simple guide and reference, 11, 20-52.

González, R. C., \& González, M. C. (2015). Escuela y familia. Dos pilares fundamentales para unas buenas prácticas de orientación educativa a través de las escuelas de padres. Orientación en Acción, 15-27. http://dx.doi.org/10.6018/reifop.18.2.219491

Henderson, A., \& Mapp, K. (2002). A New Wave of Evidence: The Impact of School, Family and Community Connections on Student Achievement. Annual Synthesis 2002. National Center for Family and Community Connections with Schools.

Henderson, A., Mapp, K., Johnson, V., \& Davies, D. (2007). Beyond the bake sale: The essential guide to family-school partnerships. New York: The New Press.

Hernández-Castilla, R., Murillo, F. J., \& Martínez-Garrido, C. (2016). Factores de ineficacia escolar. REICE. Revista Iberoamericana sobre Calidad, Eficacia y Cambio en Educación, 12(1), 103-118.

Herrera, S., Fernández, L., González, C., \& Nápoles, N. (2014). Propuesta de comunicación en salud bucal para niños con retraso mental ligero, padres y educadores. Revista Archivo Médico de Camagüey, 9(6).

Hornby, G. (2000). Improving parental involvement. London: Cassell.

Ibáñez, J. (2014). La participación social en la escuela pública: Un reto colectivo. Anthropos, 238, 83-102.

Jeynes, W. (2007). The relationship between parental involvement and urban secondary school student academic $\begin{array}{llll}\text { achievement: A meta-analysis. Urban } & \text { Education, }\end{array}$ http://dx.doi.org/10.1177/0042085906293818

López, C. (2014). Salud y estilos de vida de alumnos de educación primaria. Innovación educativa, 24, 289-303.

Macias, A., Gordillo, L., \& Camacho, E. (2012). Hábitos alimentarios de niños en edad escolar y el papel de la educación para la salud. Revista chilena de nutrición, 39(3), 40-43. http://dx.doi.org/10.4067/S0717-75182012000300006

Maitles, H. (2010). Citizenship initiatives and pupil values: A case study of one Scottish school's experience. Educational Review, 62(4), 391-406. http://dx.doi.org/10.1080/00131911003734662

Martínez, J., Reche, I., Cerezo, M. C., Maíquez, R., \& García, S. (2014). La participación de las familias en contextos educativos multiculturales: Hacia una escuela intercultural e inclusiva. Murcia, España: Universidad de Murcia

McMillan, J., \& Schumacher, S. (2005). Investigación educativa. Madrid, España: Pearson.

Mercado, R., \& Montaño, L. (2015). Procesos de participación entre profesoras de jardines de niños y madres de familia en actividades de enseñanza. Revista mexicana de investigación educativa, 20(65), 347-368. Retrieved from http://www.scielo.org.mx/scielo.php?script=sci_arttext\&pid=S1405-66662015000200002

Ministerio de Educación y Ciencia (M.E.C.). (1993). Temas transversales y desarrollo curricular. Madrid, España: Publicaciones del MEC.

Miranda, J., Romeu, A., Soler, J., \& Arrazola, B. (2014). Familias y escuelas: los diferentes discursos sobre la participación. Families and school: the different discourses about the participation. Revista Internacional de Políticas de Bienestar y Trabajo Social. International Welfare Policies and Social Work Journal, 65-89. http://dx.doi.org/10.15257/ehquidad.2014.0009

Moscovici, S. (1989). Psicología Social II. Barcelona, España: Paidós.

Muñoz, J. L., \& Gairín, J. (2011). Corporaciones municipales y participación en la educación. Revista de Educación, 583-605. http://dx.doi.org/10-4438/1988-592X-RE-2010-356-052

Nieda, J. (1992). Educación para la salud: educación sexual, 3. Ministerio de Educación.

Organización Mundial de la Salud (OMS). (2014, March). Las 10 causas principales de defunción en el mundo. Retrieved from http://www.who.int/mediacentre/factsheets/fs310/es/index2.html

Palomares, J., Cimarro, J., Cepero, M. D. M., Torres, B., Estévez, M., \& Martínez, R. M. (2014). Entre la teoría y la realidad: Ppiniones y creencias del profesorado sobre la transmisión y fomento de hábitos saludables, a través del deporte y el juego, en la compleja relación escuela-familia. Retrieved from http://digibug.ugr.es/bitstream/10481/33512/1/rev182ART8.pdf

Pérez-Jorge, D., \& Rodríguez, M. C. (2012). Actitudes de los maestros hacia las necesidades especiales de los 
alumnos. In O. M. Alegre (Ed.), Investigación sobre competencias y tecnología para la inclusión y la interculturalidad (pp. 180-196). Madrid, España: Arial

Pérez-Jorge, D. (2010). Actitudes y concepto de la diversidad humana: un estudio comparativo en centros educativos de Tenerife. La Laguna, España: Universidad de La Laguna.

Pérez-Jorge, D., Alegre, O. M., Rodríguez-Jiménez, M. C., Márquez-Domínguez, Y., \& Dela Rosa, M. (2016). La Identificación del conocimiento y actitudes del profesorado hacia la inclusión de los alumnos con necesidades $\begin{array}{llllll}\text { educativas especiales. } & \text { European }\end{array}$ http://dx.doi.org/10.19044/esj.2016.v12n7p64

Pérez-Jorge, D., De la Rosa-Hormiga, M., Pérez, P., Díaz-González, C. M., \& Marrero-Morales, M. S. (2015). The Identification of Knowledge and Educational Requirements for Secondary School Teachers in the Field of Health Education. Psychology, 6, 773-781. http://dx.doi.org/10.4236/psych.2015.66076

Pomerantz, E., Moorman, E., \& Litwack, S. (2007). The how, whom and why of parents' involvement in children's academic lives: More is not always better. Review of Educational Research, 77(3), 373-410. http://dx.doi.org/10.3102/003465430305567

Quarmby, T. (2013). Exploring the role of the family in the construction of young people's health discourses and dispositions. Educational Review, 65(3), 303-20. http://dx.doi.org/10.1080/00131911.2012.659658

Rosales, C. (1999). Textos para la enseñanza de los temas transversales. Santiago de Compostela, España: Tórculo.

Rosales, C. (2006). Perspectivas de educación para la salud. Santiago de Compostela, España: Tórculo.

Rosales, C. (2011). Educación para la salud, tarea compartida. Universitas Tarraconensis. Revista de Ciències de l'Educació, 35, 25-40.

Sáenz-López, P., Sicilia, A., \& Manzano, J. (2010). La opinión del profesorado sobre la enseñanza de la educación física en función del género. Revista Internacional de Medicina y Ciencias de la Actividad Física y el Deporte, 10(37), 167-180. Retrieved from http://cdeporte.rediris.es/revista/revista37/artopinion148.htm

Sahota, P., Rudolf, M., Dixey, R., Hill, A., Barth, J., \& Cade, J. (2001). Randomized controlled trial of primary school based intervention to reduce risk factors for obesity. BMJ, 323(7320), 1029-32. http://dx.doi.org/10.1136/bmj.323.7320.1029

Salinas, J., González, C. G., Fretes, G., \& Montenegro, E. (2014). Bases teóricas y metodológicas para un programa de educación en alimentación saludable en escuelas. Revista chilena de nutrición, 41(4), 343-350. http://dx.doi.org/10.4067/S0717-75182014000400001

Salinas, J., Lera, L., González, C., \& Huenchupán, C. (2012). Conocimientos y consumo alimentario en escolares, sus padres y profesores: un análisis comparativo. Revista chilena de nutrición, 39(3), 34-39. http://dx.doi.org/10.4067/S0717-75182012000300005

Seguí, P. V., \& Pérez, N. S. (2015). La participación de las familias en el análisis y la transformación de su realidad mediante un debate familiar sobre valores y convivencia. Univ. Psychol. Bogotá, colomBia, 14(1), 355-366. http://dx.doi.org/10.11144/Javeriana.upsy13-5.lpfa

Servicio Canario de Salud. (2007). Healthy Child Programme. Consejería de Sanidad (2nd ed.). Canarias, España: Consejería de Sanidad Dirección General de Programas Asistenciales, Servicio de Atención Primaria, Planificación y Evaluación.

Suárez, J. L., \& Urrego, L. M. (2015). Relación familia-escuela: Una comprensión al sentido que le dan los docentes desde sus prácticas pedagógicas en la Institución Educativa el Horro de Anserma, Caldas. Retrieved from http://ridum.umanizales.edu.co:8080/jspui/bitstream/6789/2350/1/Trabajo\%20de\%20 grado\%20relaci\%C3\%B3n\%20familia\%20escuela.pdf

Tallaferro, D. C. (2012). La formación: experiencia para el saber y la reflexión. Revista de Teoría y Didáctica de las Ciencias Sociales, 18, 113-127.

Torrecilla, F. J. M. (2008). Hacia un modelo de eficacia escolar. Estudio multinivel sobre los factores de eficacia de las escuelas españolas. REICE: Revista Electrónica Iberoamericana sobre Calidad, Eficacia y Cambio en Educación, 6(1), 4-28.

Valadez I, Villaseñor M., \& Alfaro N. (2004). Educación para la Salud: la importancia del concepto. Rev Educ Des, 33, 43-8. 
Vázquez-Morales, C. R., \& Álvarez-Gordillo, G. C. (2016). Percepción sobre la salud en estudiantes que viven en áreas de riesgo de desastres de origen hidrometeorológico: el caso de Motozintla, Chiapas, México. Población y Salud en Mesoamérica, 13(2), 1-15.

Vega, A. (Ed.) (2012). Indicadores de participación de los padres en la escuela. Un enfoque innovador para una educación de calidad. Madrid, España: Wolters Kluwer.

Vio, F. (2015). Prevención: Un desafío crítico para la Salud en Chile. Mensaje, 64(644), 50-54.

World Health Organization (WHO). (1948). World Health Organization Constitution. In Basic Documents. Geneva, Switzerland: Author.

\section{Copyrights}

Copyright for this article is retained by the author(s), with first publication rights granted to the journal.

This is an open-access article distributed under the terms and conditions of the Creative Commons Attribution license (http://creativecommons.org/licenses/by/4.0/). 